\title{
Training, Education, Research and Capacity Building Needs and Future Requirements in Applications of Geospatial Technology for Water Resources Management
}

\author{
Praveen K. Thakur ${ }^{1 *}$, S.P. Aggarwal ${ }^{1}$, Bhaskar R. Nikam ${ }^{1}$, Vaibhav Garg ${ }^{1}$, Arpit Chouksey ${ }^{1}$ and Pankaj R. Dhote ${ }^{1}$ \\ ${ }^{1}$ Water Resources Department, Indian Institute of Remote Sensing, Dehradun, (praveen, spa, bhaskarnikam, vaibhav, arpit, \\ pdh)@iirs.gov.in
}

Commission V, WG V/1

KEY WORDS: Geospatial technology, Water resources, Education and Training

\begin{abstract}
:
In India, water resources are managed at different levels, i.e. at central level by Ministry of Water Resources, River Development \& Ganga Rejuvenation, Central Water Commission and Central Ground Water Board, at states level by state water resources departments, and at local level by Municipal Corporation and Panchayati Raj Institutions (PRIs). As per India's national water policy of year 2012 focuses on adaption to climate change, enhancement of water availability, water demand management by efficient water use practices, management of floods and droughts, water supply and sanitation, trans-boundary rivers, conservation of water bodies and infrastructure, and finally research and training needs for each theme. Geospatial technology has unique role in all aforementioned themes. Therefore, research and training in use of Geospatial Technology (GST) in water sector is needed for each theme at different levels of water administration and water utilisation. The current paper discusses the existing framework and content of capacity building in water sector and geospatial technology in use at various government organizations and institutes. The major gap areas and future capacity building requirements are also highlighted, along with duration and timelines of training/capacity building programs. The use of distance learning/educations tools, social media, and e-learning are also highlighted in promoting use of GST in water sector. The emerging technological trends such as, new remote sensing sensors for measuring water cycle components, ground sensors based field instruments, cloud based data integration and computational models, webGIS based water information portals and training needs of new technologies are also emphasised.
\end{abstract}

\section{INTRODUCTION}

\subsection{Geospatial Technology Application in Water Resources}

The water sector in India is under tremendous pressure from multiple uses, limited surface and ground water resources, growing populations, less-scientific and non-sustainable water utilization. The traditional methods of mapping and monitoring of surface and ground water involves large amount of human and financial resources and provides information on point or specific area basis. In the last 40 years, the evolution of Geo-Spatial Technology (GST) have occurred, which involves integrated use of Remote Sensing (RS), Geographical Information System (GIS) and Global Navigation System of System (GNSS). The GST has proven its effectiveness in repeated and large area mapping and monitoring of all natural resources including water resources and major components of hydrological cycle (Chakraborty, 1999, 2000; Thakur et al., 2017c).

\subsection{Status of Geospatial Technology in Water Resources and Capacity Building Needs}

In the last 50 years, ever since the launch of Landsat in 1970s, and IRS in 1990s, the efforts are made to include/integrate GST with traditional methods of WRM by, using RS based Land Use Land Cover (LULC) map, generation of soil map and Digital Elevation Model (DEM) for estimating runoff potential and soil erosion of an area (Garg et al., 2012), ground water potential mapping, soil erosion, sediment yield and reservoir sedimentation assessment (Lilhare et al., 2014, Rawat et al., 2017, Foteh et al., 2018; Prasad et al., 2018), watershed delineation using DEM, economic and hydrologic evaluation of watershed management plans (Rao et al., 1994; Sharma and Thakur, 2007), flood and drought mapping, monitoring and damage assessment (Thakur and Sumangala, 2006; Padhee et al.,
2014, 2017), snow cover and glacier mapping and monitoring (Joughin et al., 2010; Kulkarni et al. 2010; Bhambari and Bolch, 2011; Kumar et al., 2011; Thakur et al., 2012; Aggarwal et al., 2014; Nikam et al., 2017; Thakur et al., 2017a,b), irrigated area and irrigation infrastructure mapping and monitoring (Roy et al., 2010; Nikam and Aggarwal, 2012; NRSC, 2018), irrigation water and supply requirement (Durga Rao et al., 2001), assessment of land use land cover \& climate change impact on water availability (Aggarwal et al., 2012; Aggarwal et al., 2016; Garg et al., 2017; Nikam et al., 2018). Most of these applications are driven by optical RS till mid-1990s, and addition of active Microwave (MW) remote sensing after mid-1990's and early 2000, with launch of ERS-1, 2 and Radarsat series of satellites (Britannica-2018, www.britannica.com/topic/list-of-satellites2024625). Many of these applications were made operational by use of optical and active MW data by erstwhile National Remote Sensing Agency (NRSA); which is now a part of Indian Space Research Organization (ISRO) as National Remote Sensing Centre (NRSC), Space Application Centre, SAC, Ahmedabad, with an active support of ISROs Regional Remote Sensing Centres (RRSC), state remote sensing centres and academic institutes. The capacity building for application of GST in Natural Resources Management (NRM) was first initiated in India during 1966 by former Indian Photo Interpretation Institute (renamed as Indian Institute of Remote Sensing in 1983 under NRSA) under Survey of India (SoI), in joint collaboration with International Training Centre (ITC) Netherlands (Van der Weele, 1976), for imparting training in applications of aerial Remote Sensing techniques in early years, and using Landsat and IRS data during mid 1970s and 1980s (Sinha, 1976). The research and capacity building needs of water sector were catered under hydro-geological theme, with many good geology and hydrology related works published during this time (Meijerink et al., 1984).

\footnotetext{
* Corresponding author
} 
The dedicated capacity building of GST applications in water resources was initiated at Indian Institute of Remote Sensing (IIRS), with formation of Water Resources Division (WRD) in the year 1986 (Chakraborti, 1991, 1993, 1999; IIRS, 2018). The initial focus of this division was to impart quality training and education in form of nine months Post Graduate Diploma (PGD) for the in-service government official and research on various contemporary and futuristic topics such as use of RS-GIS for watershed characterization and management, snowmelt runoff and flood forecasting, drought and flood studies, decision support for better irrigation water management, near real time flood monitoring, ground water prospect zoning, environmental impact assessment for water resources development projects (Chakraborti, 2000). Later in year 2002, the Master of Technology (M. Tech.) with Water Resources theme was added, and both PGD and M. Tech. Course were opened for fresh graduates and other qualified professional (Dadhwal and Raju 2006, IIRS-2018). In addition to IIRS, many institutes including Indian Institute of Technologies (IITs), National Institute of Hydrology (NIH), Roorkee and other academic institutes of India have contributed in imparting modular and short course (1-2 weeks) based training in this theme to various users (Tejpal et al., 2012).

During the last 10 years, the availability scenarios of RS data, processing algorithms and ready to use tools has changed. Revised RS data policy of Government of India (GoI), advent of google earth, availability of free Landsat and other RS data at medium to high resolution from USGS-Earth Explorer (NASA2018), IRS from ISRO-Bhuvan webGIS portal (NRSC-2018), Sentinel from ESA (ESA, 2014). Various NASA water related dedicated RS missions such as Terra/Aqua, Tropical Rainfall Measuring Mission (TRMM) (Huffman et al., 2007) are few milestones in this drastically changing scenario, where focus has shifted towards retrieval of hydrological parameters (Thakur et al., 2017c). These vast improvements in sensor and geospatial technology has opened many new applications in hydrology and water resources sector in India along with even greater need of training and capacity building to implement these application operationally. This fast evolving GST domain needs a comprehensive assessment of present status of knowledge base of the users (both existing and potential), methods for conveying knowledge of GST to various users and incorporating futuristic research in the GST education to fuel the developments in GST for tomorrow's needs.

As per latest available public data from central, state government and urban/rural water organizations, India have more than 35000 working professionals in the field of water resources development and management. Apart from government officials, there are large number of personnel from Panchayati Raj Institutions (PRIs) and Water User Organizations (WUO), directly involved in water management at local level. The Government of India (GoI) in its budgetary allocation for the year 2018-19, has allocated Rs. 5,970 billion to infrastructure related works in India (https://www.geospatialworld.net/blogs/budget2018-beneficial-indian-geospatial-industry/), which includes GoI flagship programs such as 'Smart Cities' and 'AMRUT', Prime Minister Krishi Sinchai Yojna- 'Har Khet ko Pani', which has direct relevance to water sector and GST. Due to diversity in geography, ecology, climatology, human culture in the country, the techniques required to carry out these programs will vary region to region. Therefore, requirements of GST applications in WRM capacity building for these multi skill level, variable geographical locations and different demographics will also be different. This paper makes an attempt to address some of these issues.

\subsection{Objectives}

The present paper, therefore has following objectives, with reference to the use of GST for improved water resources management in India: a) To understand and evaluate present training and education needs of GST in WRM, b) To design schema for different levels of training to various users, c) To understand the gap area and highlight new research in these areas of GST for WRM and d) To develop outline for future capacity building requirements and advances in GST for WRM.

\section{PRESENT TRAINING AND EDUCATION NEEDS OF GEOSPATIAL TECHNOLOGY IN WRM}

The present day scenario in the field of GST is ever changing and expanding with network of theme based satellites, sensors, data products, ground based sensor system connected with satellite and terrestrial based wireless communication systems, all aforesaid generating terabytes of data on daily basis (NOAA, 2018). This vast amount of data and information cannot be processed and analysed using traditional software and processing tools. Generating a usable maps and actionable knowledge from this available large datasets remains the biggest challenge. The expertise level of users, of the GST, remains at basic stage, and very few organization and motivated individuals explore full potential of such technologies in day to day work. This aspect was well highlighted during India's first national space meet organized on Sep. 07, 2015 by ISRO on the request of Honourable Prime Minister of India, (GoI-PMO, 2015). In this meet many new applications (a total of 156 space technology application areas were identified), requirements from various ministries of GoI were identified. Many of these applications were focused on generating updated geotagged information and basic GIS layers of various themes including that of water resources. However, the scope of GST in improving overall WRM and associated training and education requirement is much larger as explained in subsequent sub-sections.

\subsection{Training in Geospatial Technology for WRM}

The present training requirement for the application of GST in WRM is for various government departments, and other nongovernment and academic institutes involved in water sector. The major training programs constitutes short duration courses of 1 to 2 weeks, where first week or first few days are assigned to teach the basics of RS \& GIS, and during $2^{\text {nd }}$ week or fourth day onwards, the various GST topics relevant to water resources and hydrology are covered. In addition to these type of courses, 1-5 days duration short or awareness courses are designed to basically cater for the needs of decision makers, the details of different levels of training is given in Section 3.

The capacity building network of ISRO such as IIRS, Dehradun Training \& Education Division of NRSC, Hyderabad and Training and Research in Earth Eco-System (TREES) under Visualization of Earth Data and Archival System (VEDAS) of SAC, Ahmedabad are nodal centres for training in GST applications of NRM including WRM. The main topics of WRM covered under these training programs are: Role of RS \& GIS in hydrological and hydraulic modelling; wetland mapping; irrigation water management; EIA of water hydro power and water resources projects; cryosphere applications; ground water prospecting and modelling; flood mapping, monitoring and modelling studies; hydro-meteorological disaster studies; surface water mapping and reservoirs sedimentation; urban water studies and watershed management. In addition to ISRO efforts, Department of Science and Technology (DST) under GoI also 
sponsors short training programs of GST in various academic institutes in India with focus on NRM, including WRM as part of Natural Resources Data Management System (NRDMS) of DST.

The National Hydrology Project (NHP), one of the main project of Ministry of Water Resources, River Development \& Ganga Rejuvenation (MoWRRDGR), GoI, has outlined various project and training modules, which are focused on use of RS \& GIS in operational works such as, surface water, ground water, hydrological modelling, irrigation and many WRM related projects of NHP (NHP-2018a). As part of NHP training activities, more than $20 \mathrm{RS} \&$ GIS related training programs have been completed for officers of state and central water resources departments (NHP-2018b), by NRSC Hyderabad, NIH Roorkee, Department of Hydrology, IIT Roorkee, Survey of India (SoI) Dehradun and other involved academic institutes.

2.1.1 Different training needed in different geographical region of India: The Indian region has 20 major river basins, with large spatio-temporal variations in the physical, geographical attributes such as elevation, temperature, rainfall, soils and geology (Figures 1, 2 and 3). This is combined with the large variations in the population density, agricultural and industries practices, which in turn affect the water use and demand, from one region/basin/watershed to other. These physical and socio-economic variations result in large hydrological changes, such as presence of glaciers in high altitudes of Himalaya, seasonal snow in middle Himalaya, alluvial region in Indo-Gangetic plains, deserts in arid Western region, rainfall excess in regions in North-Eastern India, hard rock area in Central and Southern India, etc. These hydrometrological and physical variations can cause occurrence of water scarcity (drought), and excess water (flood), snowfall at the same time in some parts of country.

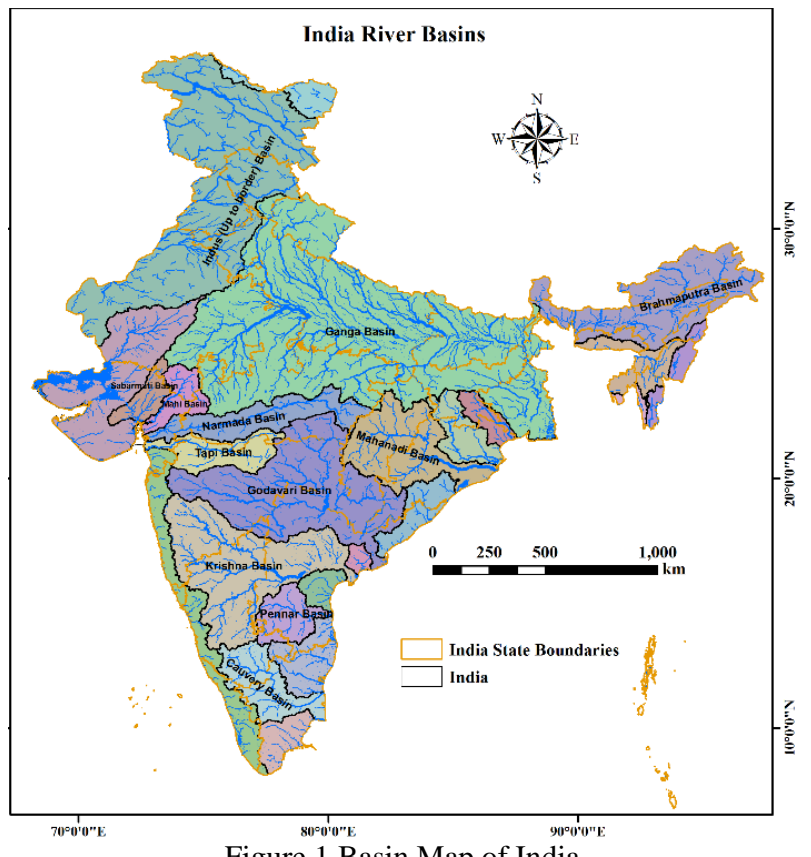

Figure 1 Basin Map of India

Therefore, the research and training requirements of GST varies with river basin, states, target level of users, and scale of water resources, i.e., basin to watershed to individual house or farm level. The example of such cases are, in the Himalayan region such as Leh, Ladakh, Lahaul \& Spiti, the harvesting of seasonal snow and ice is most important, whereas, in the hard rock areas of southern India, winter monsoon and management of tanks, ponds/reservoirs is essential. Similarly, in the Eastern India, flood management remains a big challenge, whereas, water storage and conservation remains the top priorities in arid areas of Western India. The Table 1 summarises of present capacity building needs of various user.

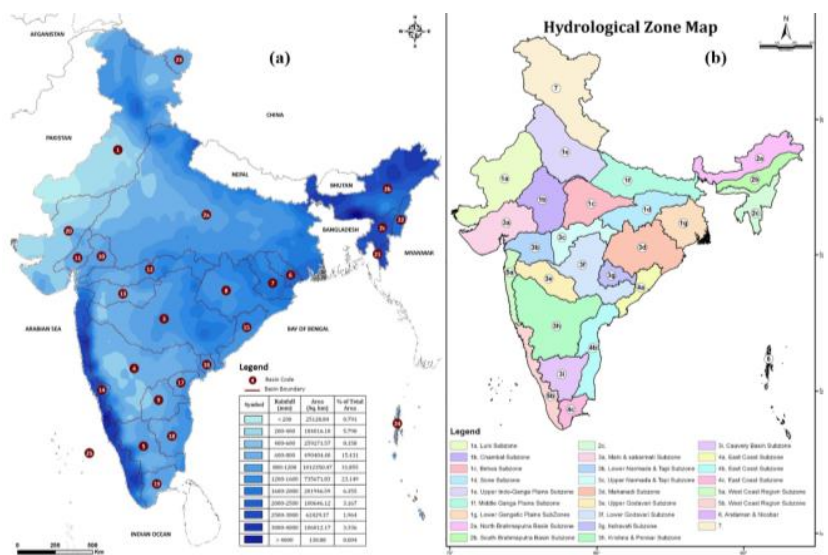

Figure 2 a) Annual average rainfall, b) Hydrological zone; map of India (Source: India-WRIS)

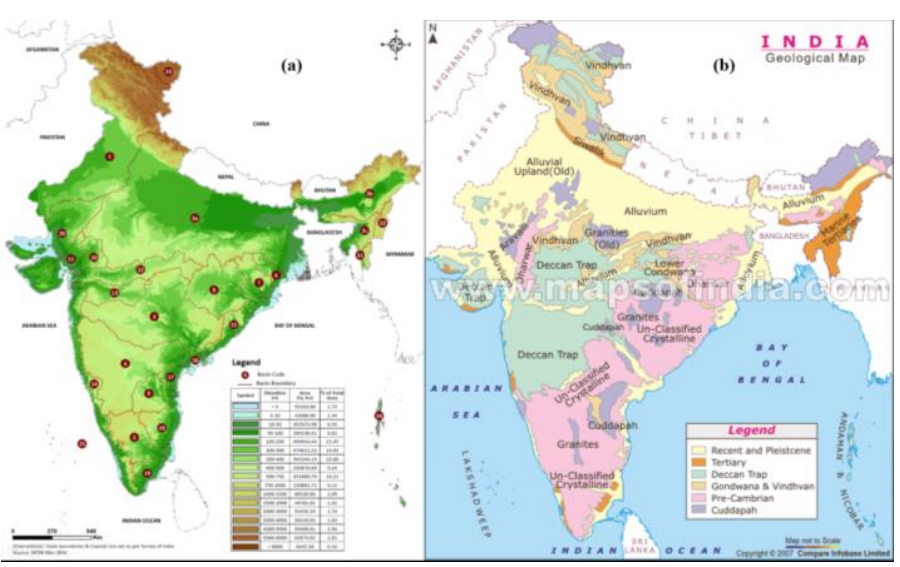

Figure 3 a) Digital Elevation Model; b) Geological Map of India (Source: India-WRIS and Maps of India).

\subsection{Education in Geospatial Technology for WRM}

The education or longer learning courses are essential to get the in depth knowledge of RS, GIS, GNSS and other GST technologies for better understanding of theme. The premier institutes in India responsible for conducting GST based educational courses for the water professionals and graduate/post graduate students are, IIRS-ISRO Dehradun (IIRS-2018), UN sponsored CSSTEAP Dehradun, IITs (Roorkee, Delhi, Bombay, Kanpur, Chennai, Ahmedabad, etc.), Anna University, Andhra University, few NITs \& central universities, deemed universities e.g. Amity university, UPES Dehradun, and other academic institutes of India. Apart from these institutes and university, the ISRO centres such as SAC, Ahmedabad and NRSC Hyderabad, various RRSC also provide supervision of long duration (more than 3 months to external $\mathrm{PhDs}$ ) projects of Master/PhD students of India (SAC-VEDAS).

At the international level, ITC, Faculty of Geo-information Science and Earth Observation, with University of Twente, and IHE Delft Institute for Water Education, both located at The Netherlands, are the premier educational institutes working since 1950s, where many Indian water professional have been trained in the field GST and WRM. 
The curriculum of these post graduate and graduate courses includes modular and semester based structure, where basic of photogrammetry, RS, GIS and GNSS is generally covered in one module or semester and thematic specialization are covered in next module/semester (IIRS-2018). The significant amount of time is devoted for practical and field sessions, so that trainees get hands-on experience in relating RS based images with actual ground reality.

Water Resources Department of IIRS, since its inception (1986) has trained 50 government officers through Post Graduate Diploma (PGD) course, with 10 trainees since 2001 and 02 government officers through M.Tech course, since start of M.Tech. in 2003. The number of fresh students/other trainees graduated in PGD and M. Tech., are 55 and 48, respectively. It is to noteworthy that, since 2002 , there has drastic decline in the number of government sponsored officers for certificate/PGD/M. Tech., courses, with only 12 officers. This declining trend is also seen in other disciplines of NRM, mainly due to difficult in getting permission and government sponsorship for such long duration courses. Many government officers have preferred short duration certificate courses, with duration of two weeks or 1-2 months for getting knowledge of GST in WRM. The details of such courses and multi-level training is given in the next section.

\begin{tabular}{|l|l|l|}
\hline S.No & Type of agency & List/Name of Departments/Agencies \\
\hline 1. & $\begin{array}{l}\text { Central } \\
\text { Government }\end{array}$ & $\begin{array}{l}\text { CWC, CGWB, CWPRS, CPCB, NWA, } \\
\text { etc. }\end{array}$ \\
\hline 2. & $\begin{array}{l}\text { Autonomous } \\
\text { Bodies under } \\
\text { Central and State } \\
\text { Governments }\end{array}$ & $\begin{array}{l}\text { National Institute of Hydrology (NIH), } \\
\text { Water and Land Management } \\
\text { Institutes (WALMIs) in different }\end{array}$ \\
\hline States, etc.
\end{tabular}

Present Capacity Building Status and Needs in use of GST for WRM

Medium to High, Operational use of RS-GIS in many projects by CWC and CGWB, e.g., India-WRIS by CWC and ISRO, NGLM project by CGWB and ISRO. Need awareness to medium level of capacity building. Low to medium use by CWPRS and NWA, need medium to high level training

Medium to High use by NIH, Dedicated RS\&GIS lab are available, low to medium use by WALMIs; Need dedicated training on advances in GST \& its application in WRM

Low use by state departments in operation projects and day to day work, knowledge level is also low, Need of multi-level customised, few departments have initiated the training activity and development of dedicated section to handle these aspects however, training of trainers is also needed.

Low use in Panchayati Raj, knowledge level is also low, however many states have inducted special cells in the Panchayati Raj Training institutes for imparting awareness training to the personnel involved in Panchayati Raj, many apps \& portals are available e.g. bhuvan-Panchayat; Drishti; Shrsiti; etc. However, there is great need of awareness training, which can best be met through distance learning mode in regional languages

Low to Medium awareness and use of GST in WRM, however lack of facilities and standards, medium to high need of multi-level training for these organisations and involvement of these trained personnel in spreading awareness among the users is needed

Medium to high level of know lade of GST, Medium to high level infrastructure availability, low to medium application of GST in WRM, Need of training on advances in application of GST in WRM

Table 1 . Summary of present capacity building status and needs in different organisation and agencies in the country.

\section{DIFFERENT LEVELS OF TRAINING AND EDUCATION IN WATER RESOURCES}

The Figure 4 shows the basic structure of major multi-level short duration training programs of GST applications in hydrological and WRM studies. Some of these multi-level training program can also be conducted in distance learning (DL) mode, as demonstrated and practiced by IIRS, Dehradun and National Water Academy (NWA), Pune, with NWA focusing dedicatedly on WRM (NWA-2018). However, many of the training program organised by IIRS are exclusively targeted to the university faculty and international participants, e.g., ISRO sponsored two months duration NNRMS training course for university teachers and faculty of academic/training institutes, the Ministry of External Affairs (MEA) of GoI sponsored two month ITEC course on RS and GIS, and during both these courses trainees can opt for WRM related thematic specialization and pilot projects.

The multi-level trainings given in Figure 4 are directly applicable to government official and water professional. The same multi- level programme and their contents cannot be applied to other stakeholders, which are mentioned in the Section 1.2 and 2.1.1.

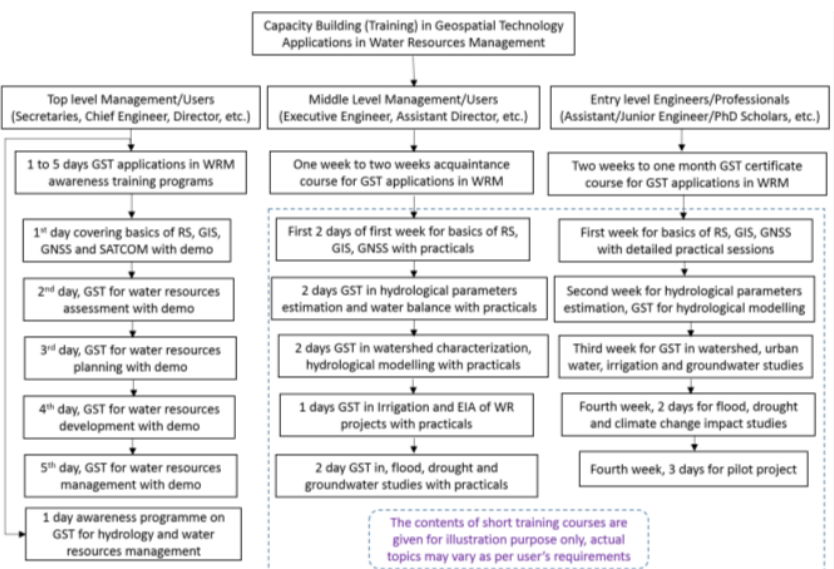

Figure 4. Overall structure of multi-level training in GST applications in hydrology and WRM. 
The large number of personnel from PRIs/WUOs and NGO, are actively involved in water management at community and local level, however do not have formal education in the hydrology, water resources or GST. These personnel need separate set of training tools, techniques and learning modules, which are easy to understand, use and implement in real world water management scenarios. The nearest contact points for village level users, NGO are BDO, KVK's and Panchayat. The first level of GST transfer using mobile based applications can be given to these officers, Gram Pradhan and nodal person of each Panchayat. This concept is implemented successfully by NRSC Hyderabad using its Drishti and Shrsiti geo-portal and mobile apps (NRSC-2017).

\begin{tabular}{|c|c|c|c|}
\hline S.No & $\begin{array}{l}\text { GST application gap area as per } \\
\text { user requirement }\end{array}$ & $\begin{array}{l}\text { Existing and emerging geospatial } \\
\text { technology and sensors }\end{array}$ & Research needs in GST sensors and applications \\
\hline 1 & $\begin{array}{l}\text { High resolution DEM for watershed, } \\
\text { flood and WR projects studies }\end{array}$ & $\begin{array}{l}\text { Very High Resolution (VHR) optical stereo } \\
\text { sensors and InSAR from ISRO, DLR, Digital Globe } \\
\text { and other space agencies/ companies. Air and } \\
\text { UAV based photogrammetric and LIDAR sensors }\end{array}$ & $\begin{array}{l}\text { New innovative techniques to generate DEM/DSM from } \\
\text { multiple stereo and InSAR images at high resolution of } \\
\text { better than } 3 \mathrm{~m} \text { and better than } 20 \mathrm{~cm} \text { using Air/UAV } \\
\text { based sensors. }\end{array}$ \\
\hline 2 & $\begin{array}{l}\text { Operational surface and root zone } \\
\text { soil moisture product at daily to } \\
\text { sub-daily interval }\end{array}$ & $\begin{array}{l}\text { New sensors such as SMOS, SMAP, NovaSAR etc. } \\
\text { and Land Surface Models (LSMs) }\end{array}$ & $\begin{array}{l}\text { Improved retrieval and data assimilation algorithms for } \\
\text { satellite based soil moisture, and forecast of top surface } \\
\text { and root zone soil moisture using calibrated LSMs }\end{array}$ \\
\hline 3 & Rain/snow water harvesting & $\begin{array}{l}\text { VHR sensors, high resolution DEM, satellite } \\
\text { based precipitation products }\end{array}$ & $\begin{array}{l}\text { Detailed case studies in various agro-climatic zone and } \\
\text { implemented project monitoring }\end{array}$ \\
\hline 4 & $\begin{array}{l}\text { Near real time flood monitoring, } \\
\text { urban flooding and forecasting }\end{array}$ & $\begin{array}{l}\text { High temporal SAR/optical data, satellite based } \\
\text { water level/discharge, improved weather } \\
\text { forecast and communication }\end{array}$ & $\begin{array}{l}\text { Flood mapping and monitoring in urban/forested areas, } \\
\text { Integration of weather forecast outputs with } \\
\text { hydrological models }\end{array}$ \\
\hline 6 & Water quality of river and lakes & $\begin{array}{l}\text { Optical sensor from Visible (VIS) to Infrared (IR) } \\
\text { region, high resolution hyperspectral sensors }\end{array}$ & $\begin{array}{l}\text { Extensive calibration and validation of satellite based } \\
\text { water quality models and their operationalization to } \\
\text { critical river reaches and lakes }\end{array}$ \\
\hline 7 & $\begin{array}{l}\text { Snow Water Equivalent (SWE) and } \\
\text { Glacier Mass Balance (GMB) }\end{array}$ & $\begin{array}{l}\text { Active and passive microwave satellite sensors } \\
\text { and LSM with snow/glacier parameterization }\end{array}$ & $\begin{array}{l}\text { Improved retrieval and data assimilation algorithms for } \\
\text { satellite based SWE, and calibrated LSMs models; } \\
\text { improvements in satellite based glacier zones and ice } \\
\text { velocity/depth maps and integration with GMB models }\end{array}$ \\
\hline 8 & $\begin{array}{l}\text { Ground water (GW) quality and } \\
\text { quantity in present and future } \\
\text { scenarios }\end{array}$ & $\begin{array}{l}\text { RS-GIS for quality and quantity prospecting, } \\
\text { gravity based satellites (GRACE, GRACE-FO), GW } \\
\text { models }\end{array}$ & $\begin{array}{l}\text { Aquifer mapping, downscaling of GW quantity data } \\
\text { gravity based sensors, calibration and validation of GW } \\
\text { models }\end{array}$ \\
\hline 9 & $\begin{array}{l}\text { Water availability at } \\
\text { village/city/watershed/basin scale }\end{array}$ & $\begin{array}{l}\text { VHR optical sensors, HR DEMs, GIS based water } \\
\text { database (India-WRIS), hydrological models }\end{array}$ & $\begin{array}{l}\text { Accurate and high resolution hydro-meteorological data } \\
\text { creation, multi-scale, calibrated and validated } \\
\text { hydrological models }\end{array}$ \\
\hline
\end{tabular}

Table 2. GST application gap areas, user requirement, present capacity and future research needs.

\subsection{GAP AREAS AND GST RESEARCH NEEDS FOR BETTER WRM}

The traditional and operational applications of GST in WRM are discussed in the previous sections. The last 10 years have seen emergence of newer GST applications and maturity of previous research oriented application in WRM, mainly due to the availability of large amount of satellite data and new sensors related to hydrology \& WR and tremendous increase in computational power and communication technologies. The few of these emerging geospatial technologies, their applications domains, gap area as per user requirement and further research requirement are given in Table 2 .

\subsection{FUTURE CAPACITY BUILDING REQUIREMENTS AND ADVANCES IN GST FOR WRM}

As discussed previously, the GST and associated applications are developing at fast speed in recent times. It is also evident from Tables $1 \& 2$ that present capabilities of GST are also not fully utilised in WRM due to lack of knowledge about these techniques among many of the users. However, owing importance of water resources for human life, coming decades are going to witness more and more dedicated remote sensing missions for water resources. New satellites such as, Surface Water Ocean Topography (SWOT) Mission, NASA-ISRO SAR (NISAR), GeoHR, Cartosat-2\&3 series are some of the planned mission by different space organisations. However, the utilisation of existing and future remote sensing mission for improvement in WRM depends on awareness among user community about usefulness of these datasets and enhanced data products. For example, under Hydrology Project II, real time stream flow forecast systems have been developed for Bhakra Beas Management Board, BBMB (Punjab, HP) and Krishna-Bhima Basin (Maharashtra). Real time hydro-met data acquisition network has been implemented under this project which provides key inputs (ground observed data) required for forecasting inflows into the reservoirs to form the basis for reservoir operation decision making and providing flood early warnings to communities under real time decision support system (RTDSS). It is an expensive and time-consuming task to maintain such data acquisition network. Remote sensing inventions such as satellite based rainfall and altimetry have shown its potential to monitor inland water bodies at regular and longer period of time (Birkett et al., 2002; Prakash et al., 2016) Previous altimeter missions (ERS2, ENVISAT, Topex/Poseidon) and present missions (Jason-2 and SARALAltiKa) have shown there potential to monitor river water level (Papa et al., 2010; Dubey et al., 2015; Gosh et al., 2017). An attempt should be made via capacity building to consider altimetry technique as part of data acquisition network. Similar examples are also available in the sector of watershed management, snowmelt runoff, water quality monitoring, irrigation water management, etc. Hence, there is need to list out future sensors/satellites having potential in improving WRM with the list of domains in which each of these future mission can contribute in water resources. The scope of capacity building among different users should also be 
analysed and put forward which will assist the institutes, involved in capacity building of users in the field of application of GST in WRM, in evolving future strategy/road map to cater for this upcoming demand. The brief listing of future satellites/sensors having major applications in WRM is done in Table 3, the new geospatial products related to WRM from these mission are also listed in this table with scope of capacity building, including use of Distance Learning (DL) tools, such as, e-learning, webinars, etc., among the different users for utilising these datasets and products in WRM. These DL tools can help reach large number of WRM users of GST in vast country like India.

\begin{tabular}{|c|c|c|c|}
\hline $\begin{array}{l}\text { S. } \\
\text { No }\end{array}$ & $\begin{array}{l}\text { Current Advanced and } \\
\text { Future satellites/sensors }\end{array}$ & $\begin{array}{l}\text { New geospatial products related to } \\
\text { hydrology and WRM }\end{array}$ & $\begin{array}{l}\text { Scope of capacity building status and needs in use of } \\
\text { future GST tools/techniques/products for WRM }\end{array}$ \\
\hline 2 & $\begin{array}{l}\text { Very high resolution } \\
\text { optical sensors (PAN and } \\
\text { MX) with stereo capability }\end{array}$ & $\begin{array}{l}\text { Water infrastructure mapping, glacial lake } \\
\text { monitoring, DEM generation \& terrain } \\
\text { parameters extraction }\end{array}$ & $\begin{array}{l}\text { Low to Medium need of capacity building for academic } \\
\& \text { research Institutions, High need of capacity building } \\
\text { and technology transfer to line departments working } \\
\text { in WRM. }\end{array}$ \\
\hline 3 & $\begin{array}{l}\text { High spatial and temporal } \\
\text { resolution SAR, InSAR, } \\
\text { PolSAR, Pol-InSAR Sensors } \\
\text { with (through } \\
\text { constellation of satellites) }\end{array}$ & $\begin{array}{l}\text { Water body mapping, snow cover } \\
\text { mapping, snow physical parameter } \\
\text { (SCA/density/wetness) retrieval, top } \\
\text { surface soil moisture assessment, DEM } \\
\text { generation \& terrain parameter extraction, } \\
\text { glacier/ice sheet velocity; elevation change } \\
\text { \& features assessment, flood mapping and } \\
\text { monitoring }\end{array}$ & $\begin{array}{l}\text { High need of capacity building in Academic and } \\
\text { research Organisations, very high need of capacity in } \\
\text { utilisation of SAR data in flood mapping, geo-physical } \\
\text { parameter retrieval related to WRM for other } \\
\text { agencies. High need of awareness among user } \\
\text { departments about capability and utilisation of these } \\
\text { datasets and their derivatives in WRM. }\end{array}$ \\
\hline 4 & $\begin{array}{l}\text { High resolution } \\
\text { Hyperspectral sensors } \\
\text { (constellation/geo } \\
\text { satellites) }\end{array}$ & $\begin{array}{l}\text { Water quality monitoring, retrieval of snow } \\
\text { grain size, snow wetness, bear soil } \\
\text { moisture and crop water stress }\end{array}$ & $\begin{array}{l}\text { High need of capacity building in application of these } \\
\text { datasets in WRM among all the levels of users, Very } \\
\text { high need of awareness among decision makers. }\end{array}$ \\
\hline 5 & $\begin{array}{l}\text { Pulse based and } \\
\text { interferometric Altimeters }\end{array}$ & $\begin{array}{l}\text { Rive discharge estimation, water level } \\
\text { monitoring, flood monitoring, reservoir } \\
\text { sedimentations assessment, Glacier/lce } \\
\text { Sheet Velocity, elevation change }\end{array}$ & $\begin{array}{l}\text { Very high need of capacity building among researchers } \\
\text { and academicians on utilisation of these data for WRM } \\
\text { and algorithm development for retrieval of geo- } \\
\text { physical parameters, Very high need of spreading } \\
\text { awareness about these datasets and their derivative } \\
\text { among the decision maker and other levels of users. }\end{array}$ \\
\hline 7 & LiDAR Sensors & $\begin{array}{l}\text { DEM generation and terrain parameter } \\
\text { extraction, water level \& bathymetry, } \\
\text { Glacier/Ice Sheet Velocity, elevation } \\
\text { change and features Assessment }\end{array}$ & $\begin{array}{l}\text { Vey high need of spreading awareness about these } \\
\text { applications, high need of involving Academic \& } \\
\text { research institutes in detailed capacity building on } \\
\text { these applications }\end{array}$ \\
\hline 8 & $\begin{array}{l}\text { Passive Microwave Passive } \\
\text { MW radiometers with } \\
\text { concurrent active MW } \\
\text { observation in same band. }\end{array}$ & $\begin{array}{l}\text { Precipitation Retrieval, Soil Moisture } \\
\text { Retrieval, Snow Physical Parameter } \\
\text { (SCA/SWE/depth) Retrieval }\end{array}$ & $\begin{array}{l}\text { Low to medium need of capacity building in research } \\
\text { and academic institutes, high need of capacity building } \\
\text { for other users, very high need of spreading awareness }\end{array}$ \\
\hline
\end{tabular}

Table 3. Future sensors/satellites, their potential application in WRM and future capacity building scope to utilise these datasets.

\subsection{CONCLUSIONS}

The integration of Remote Sensing (RS), Geographical Information System (GIS) and Global Navigation System of System (GNSS) is termed as geospatial technology (GST). This technology involves sensors for acquiring data, systems for storing and processing data and personnel to utilise these data products. The personnel involved in processing these spatial datasets are called geo-researcher and personnel involved in utilising these data products are geo-users. Geospatial technology has shown huge potential in improving water resources management through mapping, monitoring and retrieving various hydrological components at synoptic and repeated scales.
To enhance the knowledge of geo-researcher, geo-users working in the water resources domain and its stakeholders, Government of India has been emphasising on capacity building of these personnel. Indian Institute of Remote Sensing, ISRO, Dehradun, since its inception, has shouldered the responsibility of capacity building of geo-researchers and geo-users in the field of application of GST in improving WRM. However, the diversity of geography, climate, culture, languages in India demands for customization of these capacity building programmes. In the present paper, the current status of knowledge and utilisation of GST in various user agencies and departments working in WRM is analysed, so as to understand the present need of capacity building in the field of application of GST in WRM. Multi-level structured training programmes in GST applications for WRM is also proposed for various users, i.e., from senior most managers 
to actual working level professionals. The gap areas in GST applications and user requirements are compared with the existing and emerging GST/sensors. The research impetus that can be drawn from these gap areas and emerging sensors are also discussed in this paper. The future satellite missions their sensors and capabilities for helping improve WRM is analysed and the respective geospatial products form each future mission/sensor and scope of future capacity building activity has been listed along with these products.

It is discussed with examples, that GST and related techniques can significantly improve the management of water resources at much less cost, higher accuracy and with much larger spatial coverage. Many of the water resources management problems faced today by the water resources managers can be solved by integrating GST in the traditional WRM techniques. This integration can successfully be done by combined effort of subject (WR) experts and expert of GST having basis knowledge of hydrology and water resources, proper formulation and execution of multi-level capacity building programs.

\section{REFERENCES}

Aggarwal, S. P., Garg, V., Gupta, P. K., Nikam, B. R. and Thakur, P. K. 2012. Climate and LULC Change Scenarios to Study its Impact on Hydrological Regime. International Archives of the Photogrammetry, Remote Sensing and Spatial Information Sciences, XXXIX-B8, pp.147152, doi:10.5194/isprsarchives-XXXIX-B8-147-2012.

Aggarwal, S.P., Thakur, P.K., Nikam, B.R. and Garg, V., 2014 Integrated approach for Snowmelt Runoff Estimation using Temperature Index Model, Remote sensing and GIS. Curr Sci., 106(3), pp.397-407.

Aggarwal, S.P., Thakur, P. K., Garg, V., Nikam, B. R., Chouksey, A., Dhote, P. and Bhattacharya, T., 2016. Water Resources Status and Availability Assessment in Current and Future Climate Change Scenarios for Beas River Basin of North Western Himalaya. The International Archives of the Photogrammetry, Remote Sensing and Spatial Information Sciences (ISPRS), XLI-B8, pp.1389-1396, doi:10.5194/isprs-archives-XLI-B8-1389-2016

Bhambri, R., Bolch, T., Chaujar, R.K. and Kulshreshtha, S.C., 2011. Glacier changes in the Garhwal Himalaya, India, from 1968 to 2006 based on remote sensing. Journal of Glaciology, 57(203), pp.543-556

Bhan, S. K., 1997. Training and Education in Remote Sensing, Journal of the Indian Society of Remote Sensing, 25(1), pp.1-18.

Birkett, C. M., Mertes, L. A. K., Dunne, T., Costa, M. H., Jasinski, M. J., 2002. Surface water dynamics in the Amazon Basin: Application of satellite radar altimetry, J. Geophys. Res., 107(D20), 8059, doi:10.1029/2001JD000609.

Chakraborti, A. K., 2000. Achievements in Use of Satellite Remote Sensing in Practical Water Resources Management in India - What is needed for Further Integration. Selected Papers from Activities held in 1999. Seminars of the United Nations Programme on Space Applications, United Nations, New York, 11, pp.85-102.

Chakraborti, A.K., 1991. Sediment Yield Prediction and Prioritisation of Watersheds Using Remote Sensing Data, in proceedings of the $12^{\text {th }}$ Asian Conferences on Remote Sensing, Singapore, P.Q-3-1 Q-3-6

Chakraborti, A.K., 1992. Remote Sensing Applications in Water Resources Development in India, in Development of hydrology in India since Independence. Special publication, NIH Roorkee, pp.73-97

Chakraborti, A.K., 1993. State-of-Art in Research towards Operationalisation of Remote Sensing Applications in Water Resources in India, in Proceeding of the International Symposium on 'Operationalisation of remote Sensing', ITC, Enschede, The Netherlands, VI, pp.149-160.

Chakraborti, A.K., 1999. Satellite Remote Sensing for Near-Real-Time Flood and Drought Impact Assessment-Indian Experience, in PreConference proceedings of the International Conference on "Geoinformatics Beyond 2000", IIRS, Dehradun, India, pp.129-137.

Dadhwal, V.K. and Raju, P.L.N., 2006. 40 Years of IIRS - ITC Collaboration - Achievements \& Future Directions,
Commemorative Workshop- 40 YEARS AND BEYOND, IIRS \& ITC Collaboration in Capacity Building, Nov 28-29, 2006, IIRS Dehradun.

Dubey, A.Y., Gupta, P., Dutta, S. and Singh, R.P., 2015. Water Level Retrieval Using SARAL/AltiKa Observations in the Braided Brahmaputra River, Eastern India, Marine Geodesy, 38:sup1, pp.549567, doi:10.1080/01490419.2015.1008156

Durga Rao, K.H.V., Kumar, C.S.K. and Prasad, V.H., 2001. Irrigation water requirements and supply analysis in Dehradun region-an integrated remote sensing and GIS approach. J Indian Soc Remote Sens., 29(1\&2), pp.59-67.

Dutt, C.B.S., Ganesha R. K., and Gupta, A. K., 1992. Remote Sensing Training and Educational Opportunities in India in Natural Resource Management - A New Perspective. National Natural Resources Management System (NNRMS), Bangalore.

Foteh, R., Garg, V., Nikam B. R., Khadatare, M. Y., Aggarwal, S. P., Senthil Kumar, A., 2018. Reservoir Sedimentation Assessment through Remote Sensing and Hydrological Modeling. Journal of the Indian Society of Remote Sensing, doi:10.1007/s12524-018-0843-6.

Garg, V., Khwanchanok, A., Gupta, P.K., Aggarwal, S.P., Kiriwongwattana, K., Thakur, P.K. and Nikam, B.R., 2012. Urbanisation Effect on Hydrological Response: A Case Study of Asan River Watershed, India. Journal of Environment and Earth Science, 2(9), pp.39-50

Garg, V., Aggarwal, S.P., Gupta, P. K., Nikam, B. R. and Thakur, P. K., 2017. Assessment of land use land cover change impact on hydrological regime of a basin. Environmental Earth Sciences, 76: 635 doi 10.1007/s12665-017-6976-z.

Ghosh, S., Thakur, P.K., Sharma, R., Nandy, S., Garg, V., Amarnath, G. and Bhattacharyya, S., 2017. The potential applications of satellite altimetry with SARAL/AltiKa for Indian inland waters. Proceedings of the National Academy of Sciences, India Section A: Physical Sciences, 87(4), pp.661-677.

Huffman, G.J., Adler, R.F., Bolvin, D.T., Gu, G., Nelkin, E.J., Bowman, K.P., Hong, Y., Stocker, E.F. and Wolf, D.B., 2007. The TRMM multi satellite precipitation analysis (TMPA): quasi-global multiyear, combined-sensor precipitation estimates at fine scales. J Hydro Meteorol., 8, pp.38-55.

Joughin, I., Smith, B.E. and Abdalati, W., 2010. Glaciological advances made with interferometric synthetic aperture radar. Journal of Glaciology, 56(200), pp.1026-1041

Kulkarni, A., Rathore, B.P., Singh, S.K. and Ajai, A., 2010. Distribution of seasonal snow cover in central and Western Himalaya. Ann Glaciol., 51(54), pp.121-128.

Kumar, P., Tiwari. K.N. and Pal, D.K., 1991. Establishing SCS Runoff Curve Number from IRS Digital Data Base. Photonirvachak, Journal of the Indian Society of Remote Sensing, 19(4), pp.245-251.

Kumar, V., Venkataramana, G. and Hogda, K.A., 2011. Glacier surface velocity estimation using SAR interferometry technique applying ascending and descending passes in Himalaya. Int $J$ Appl Earth Obs Geoinform., 13, pp.545-551.

Lilhare, R., Garg, V. and Nikam, B. R., 2014. Application of GIS Coupled Modified MMF Model to Estimate Sediment Yield on a Watershed Scale. Journal of Hydrologic Engineering, 20(6), C50140021:16. doi. 10.1061/(ASCE)HE.1943-5584.0001063

Meijerink, A.M.J., de Brouwer, H.A.M., Mannaerts, C.M. and Valenzuela, C.R., 1994. Introduction to the use of Geographic Information Systems for practical hydrology. UNESCO/ITC publ. No. 23.

Meijerink, A.M.J., Rao, D.P. and Rupke, J., 1984. Stratigraphy and structural development of the Precambrian Cuddapah Basin, SE India. Precambrian Research, 26, pp.57-104.

Nikam B.R. and Aggarwal S.P., 2012. Assessment of Irrigation Potential Created in AIBP funded 50 Irrigation Projects using Cartosat DataEastern Ganga Canal Projects Uttar Pradesh. (DCN: NRSC-RSAAWRG-AIBP50-Jul-2012-TR-424)

Nikam, B.R., Garg, V., Gupta, P. K., Thakur, P. K., Kumar, A. S., Chouksey, A., Aggarwal, S. P., Dhote, P. and Purohit, S., 2017. Satellite Based Mapping and Monitoring of Heavy Snowfall in North Western Himalaya and its Hydrologic Consequences. Current Science, 113 (12), pp.2328-2334. 
Nikam, B.R., Garg, V., Jaya, K., Gupta, P.K., Srivastav, S.K., Thakur, P.K. and Aggarwal, S.P., 2018. Analyzing Future Water Availability and Hydrological Extremes in Krishna Basin under Changing Climatic Conditions. Arabian Journal of Geosciences, 11(19):581, 10.1007/s12517-018-3936-1

Padhee, S. K., Nikam, B. R., Aggarwal, S. P. and Garg, V., 2014. Integrating Effective Drought Index (EDI) and Remote Sensing Derived Parameters for Agricultural Drought Assessment and Prediction in Bundelkhand Region of India. The International Archives of the Photogrammetry, Remote Sensing and Spatial Information Sciences (ISPRS), XI(8), pp.89-100.

Padhee, S., Nikam, B. R., Dutta, S. and Aggarwal S. P., 2017. Using satellite based soil moisture to detect and monitor spatiotemporal traces of agricultural drought over Bundelkhand region of India. GIScience Remote Sensing, 54(2), pp.144-166.

Papa, F., Durand, F., Rossow, W. B., Rahman, A., Bala S. K., 2010. Satellite altimeter-derived monthly discharge of the Ganga-Brahmaputra River and its seasonal to interannual variations from 1993 to 2008, $J$. Geophys. Res., 115, C12013.

Prakash, S., Mitra, A.K., Pai, D.S. and Agha Kouchak, A., 2016. From TRMM to GPM: how well can heavy rainfall be detected from space? Adv Water Resour., 88, pp.1-7

Prasad, N.R., Garg, V., Thakur, P.K., 2018. Role of SAR Data in Water Body Mapping and Reservoir Sedimentation Assessment. In the ISPRS Annals of the Photogrammetry, Remote Sensing and Spatial Information Sciences, Volume V-1, ISPRS TC V Mid Term Symposium on "Education \& Outreach - Geospatial technology - Pixel to People", Dehradun, India, during November 20 - 23, 2018.

Raju, P.L.N., and Dadhwal, V.K., 2007. Four decades of capacity building in applications of space-based earth observation and Geoinformatics at Indian Institute of Remote Sensing, Proceedings of 58th International Astronautical Congress, organized at NRSA, Hyderabad during Sept. 24-28, 2007. IAC-07-E1.I.08.

Raju, P.L.N., Dadhwal, V.K. and Jeganathan, C., 2007. GIS Education and Training at Indian Institute of Remote Sensing, GIS Development, Asia Pacific, Mach 2007, 11(3).

Rao, S. Y. and Jugran, D.K., 2003. Delineation of groundwater potential zones and zones of groundwater quality suitable for domestic purposes using remote sensing and GIS, Hydrological Sciences-Journal - des Sciences Hydrologiques, 48(5), pp.821-833.

Rao, V.V., Chakraborti, A.K., Vaz, N., Sarma, U. 1994. Watershed Prioritisation based on sediment Yield Model and IRS-1A LISS data, Asian Pacific Journal on Remote Sensing, 6 (2), pp.87-97.

Rawat, S., Jain, M.K., Rawat, K.S., Nikam, B. R. and Mishra, S.K., 2017. Vulnerability Assessment of Soil Erosion/Deposition in a Himalayan Watershed using a Remote Sensing and GIS Based Sediment Yield Model. International Journal of Current Microbiology and Applied Sciences, 6 (3), pp.40-56.

Roy, P.S., Dwivedi R.S. and Vijayan, D., 2010. Remote Sensing Applications. National Remote Sensing Centre, ISRO, Hyderabad. ISBN 978-81-909460-0-1.

RT-DSS., 2015. Innovative Real Time Decision Support System For Water Resources And Flood Management In India - Hydrology Project II [online]. Available from: http://hydrologyproject.gov.in/PDF/RTDSS.pdf [Accessed 28 Sep 2018].

Sharma, A.K. and Thakur P.K. (2007). Quantitative Assessment of Sustainability of Proposed Watershed Development Plans for Kharod Watershed, Western India. Journal of Indian Society of Remote Sensing, 35(3), pp.231-241.

Sinha, J.N., 1976. The Indian Photo-Interpretation Institute, Dehradun, India, ITC Journal - Jubilee Issue, 4, pp.713- 721.

Surendar, M., Bhattacharya, A., Singh, G., Venkataraman, G., 2015. Estimation of snow density using full-polarimetric synthetic aperture radar (SAR) data. Phys Chem Earth., 83-84, pp.156-165

Tejpal, Sharma, M. and Jaglan, M. S., 2012. Significance of Geospatial technology and status of its education and training in India. International Journal of Geomatics and Geosciences, 2(3), pp.73-737.

Thakur, P.K. and Sumangala, A., 2006. Flood Inundation Mapping and 1-D Hydrodynamic Modeling Using Remote Sensing and GIS
Techniques. The International Archives of the Photogrammetry, Remote Sensing and Spatial Information Sciences (ISPRS), XXXVI (4), pp.1-6

Thakur, P.K., Aggarwal, S.P., Garg, P.K., Garg, R.D., Mani, S., Pandit, A. and Kumar, S., (2012). Snow physical parameter estimation using space based SAR. Geocarto Int., 27, pp.263-288.

Thakur, P.K., Aggarwal, S.P., Arun, G., Sood, S., Kumar, A.S., Mani, S. and Dobhal, D.P., 2017a. Estimation of snow cover area, snow physical properties and glacier classification in parts of Western Himalaya using C-band SAR data. J Indian Soc Remote Sens. 45(3), pp.525-539.

Thakur, P.K., Garg, V., Nikam, B.R., Chouksey, A., Aggarwal, S.P. and Dhote, P.R., 2017b. Cryospheric Studies in Indian Himalayan and Polar Region: Current Status, Advances and Future Prospects of Remote Sensing. Proceedings of the National Academy of Sciences, India Section A: Physical Sciences, 87(4), pp.593-616.

Thakur, P.K., Nikam, B.R., Garg, V., Aggarwal, S.P., Chouksey, A., Dhote, P.R. and Ghosh, S., 2017c. Hydrological Parameters Estimation using Remote Sensing and GIS for Indian Region - A Review. Proceedings of the National Academy of Sciences, India Section A: Physical Sciences, 87(4), pp.641-659.

Van der Weele, Ir. A.J., 1976. Twenty-five years of education at ITC, ITC Journal - Jubilee Issue, 4, pp.605-614.

Venugopal, K., Senthil, R. and Yogendran, S., 2001. Geomatics Education in India- A View Point. Paper Presented at the $22^{\text {nd }}$ Asian Conference on Remote Sensing, November 5-9, Singapore.

Britannica, 2018. https://britannica.com/topic/list-of-satellites-2024625. Accessed on October 10, 2018

CWC, 2018. Central Water Commission, http://cwc.gov.in/ CWWB, 2018. Central Ground Water Board, http://cgwb.gov.in/ GoI-PMO, 2015. Prime Minister Office, http:// pmindia.gov.in/en/news_updates/pm-addresses-special-session-ofnational-meet-on-promoting-space-technology-based-tools-andapplications-in-governance-and-development/

IIRS-2018. Indian Institute of Remote Sensing, https:// iirs.gov.in/Academic-And-Training-Programmes

ISRO, 2018. https://isro.gov.in/. Accessed on October 10, 2018

NASA, 2018. https://landsat.usgs.gov/landsat-missions-timeline. Accessed on October 10, 2018

NHP, 2018a. National Hydrology Project http://nhp.mowr.gov.in/. Accessed on September 2018.

NHP-2018b. http://nhp.mowr.gov.in/Training.aspx. Accessed on September 30, 2018.

NOAA, 2018

https://commercedataservice.github.io/tutorial_viirs_part1/. Accessed on October 10, 2018

National Water Academy, NWA-2018. http://nwa.mah.nic.in/

NRSC-2018. www.nrsc.gov.in

http://bhuvan.nrsc.gov.in/bhuvan_links.php\#

http://dst-iget.in/

http://idup.gov.in/en

http://pib.nic.in/newsite/PrintRelease.aspx?relid=126690

http://waterresources.kar.nic.in

http://cswcrtiweb.org/training/learning/chandigarh/wua.pdf http://dst.gov.in/natural-resources-data-management-system http://panchayat.gov.in/ https://vedas.sac.gov.in/vedas/

https://geospatialworld.net/blogs/budget-2018-beneficial-indiangeospatial-industry/ 